\title{
Jednolita umowa o prace na czas nieokreślony?
}

1. Motywem przewodnim Księi Jubileuszowej Profesora Michała Seweryńskiego jest przyszłość prawa pracy. Truizmem jest stwierdzenie, że otaczający nas świat ulega fundamentalnym zmianom, a zachodzące procesy przebiegają znacznie szybciej niż jeszcze kilka dekad temu. Przekształcenia dotyczą wszystkich dziedzin życia, w tym również problematyki zatrudnienia oraz rynku pracy. Uwarunkowania tych przemian są bardzo zróżnicowane i obejmują szereg złożonych zagadnień.

W dziedzinie zatrudnienia warto zauważyć, że rozwój technologii oraz metod komunikacji wpływa na pojawienie się nowych form świadczenia pracy, czego sztandarowym przykładem jest telepraca, w naszym ustawodawstwie uregulowana w kodeksie pracy. Obok tradycyjnej umowy o pracę coraz większe znaczenie mają inne formy prawne prowadzenia aktywności zarobkowej, jak choćby umowy cywilnoprawne oraz działalność na własny rachunek (tzw. samozatrudnienie). Pojawiają się też nowe możliwości świadczenia pracy, $w$ tym zatrudnienie tymczasowe $w$ ramach agencji pracy tymczasowej, z trójstronną relacją prawną obejmującą agencję pracy tymczasowej, pracownika tymczasowego oraz pracodawcę użytkownika. Dodajmy do tego, że procesy globalizacji umożliwiają relatywnie łatwe przenoszenie produkcji z kraju do kraju czy nawet z kontynentu na kontynent, co z kolei powoduje tendencje do obniżania kosztów prowadzonej działalności, często oznaczające likwidację miejsc pracy, a także ograniczanie zakresu uprawnień pracowniczych. Nie bez znaczenia jest też kryzys gospodarczy. Warto odnotować spostrzeżenie Profesora Michała Seweryńskiego, że konsekwencją kryzysu gospodarczego jest osłabienie trwałości zatrudnienia, pogarszanie się jego warunków oraz wysokie bezrobocie. Słabnie też skłonność pracodawców do tworzenia nowych miejsc pracy, a zarazem do niepokojących rozmiarów wzrasta w Polsce skala nietrwałego zatrudnienia ${ }^{1}$. lońskiego.

${ }^{1}$ M. Seweryński, Kryzys gospodarczy i prawo pracy, [w:] G. Uścińska (red.), Prawo pracy. Refleksje i poszukiwania. Księga Jubileuszowa Profesora Jerzego Wratnego, Warszawa 2013, s. 27. 
Przedstawione wyżej czynniki w żadnej mierze nie odzwierciedlają wszystkich uwarunkowań zachodzących przeobrażeń. Trzeba jednak mieć świadomość, że tradycyjne instytucje prawa pracy ukształtowały się oraz rozwijały w zupełnie innych realiach. Przykładowo, kilkadziesiąt lat temu na naszym rynku pracy dominującą formą prawną aktywności zarobkowej była umowa o pracę na czas nieokreślony, a na jej podstawie zatrudniona była przeważająca większość osób prowadzących działalność zarobkową. W ówczesnych realiach ten stosunek prawny gwarantował zarówno stabilizację zatrudnienia, jak i odpowiednie świadczenia z zabezpieczenia społecznego. Obecnie, w epoce coraz większego zróżnicowania sytuacji prawnej uczestników rynku pracy, konieczne jest poszukiwanie nowych rozwiązań legislacyjnych. Ich celem powinno być zapewnienie adekwatnej ochrony socjalnej wszystkim osobom aktywnym zarobkowo. Dlatego też przyszłość prawa pracy rodzi wiele pytań, a kierunki dalszego rozwoju wcale nie są oczywiste czy przesądzone. Wątpliwości mogą dotyczyć nawet istnienia prawa pracy jako odrębnej gałęzi ustawodawstwa, a także jej ewentualnego przekształcenia w szerzej rozumiane prawo zatrudnienia ${ }^{2}$.

Szereg znaków zapytania budzi również przyszłość konkretnych instytucji prawa pracy. W swoim opracowaniu chciałbym zając się koncepcją jednolitej umowy o pracę na czas nieokreślony (ang. single open - ended contract). Możliwość jej wprowadzenia stanowi przedmiot dyskusji w niektórych państwach członkowskich Unii Europejskiej. Jest również objęta zainteresowaniem Komisji Europejskiej, która widzi w niej potencjalny środek polepszenia sytuacji na rynku pracy oraz ograniczenia jego segmentacji. Jak sądzę, warto zastanowić się, czy jednolita umowa o pracę może stać się jednym z elementów dalszego rozwoju prawa pracy.

2. Odchodzenie od modelu opartego na stabilnym zatrudnieniu stało się od lat osiemdziesiątych wieku XX istotną tendencją występującą w państwach ówczesnej Europejskiej Wspólnoty Gospodarczej. W znacznym stopniu było to powiązane z istniejącą wówczas sytuacją gospodarczą oraz rosnącą konkurencją. Stopniowo na coraz większą skalę zastosowanie znajdowały terminowe umowy o pracę, a także umowy o pracę $\mathrm{w}$ niepełnym wymiarze czasu pracy. W porównaniu $\mathrm{z}$ tradycyjnym stosunkiem pracy przekształcenia dotyczyły ponadto podporządkowania osoby świadczącej pracę, miejsca wykonywania działalności czy pojawienia się trójstronnych stosunków prawnych ${ }^{3}$. W latach dziewięćdziesiątych ubiegłego stulecia przeprowadzano reformy, które znacznie ułatwiły stosowanie zatrudnienia terminowego, podczas gdy ochrona trwałości

${ }^{2}$ M. Gersdorf, Prawo zatrudnienia, Warszawa 2013, s. 169 i nast.

${ }^{3}$ Uwarunkowania te omawia np. B. Veneziani, The Employment Relationship, [w:] B. Hepple, B. Veneziani (red.), The Transformation of Labour Law in Europe. A comparative study of 15 countries 1945-2004, Oxford-Portland, Oregon 2009, s. 114 i nast. 
umów bezterminowych została w zasadzie nietknięta ${ }^{4}$. Jednocześnie coraz popularniejsze stawały się formy aktywności zarobkowej, które pozostają poza zakresem prawa pracy.

Zarysowane tendencje wystąpiły również w Polsce. W naszym kraju były one dodatkowo powiązane $\mathrm{z}$ transformacją ustrojową oraz przechodzeniem do modelu gospodarki wolnorynkowej. Bez wattpienia istotne znaczenie miały ponadto postęp technologiczny tudzież nasilające się procesy globalizacyjne. $W$ piśmiennictwie podkreślono, że mamy do czynienia ze zjawiskami deregulacji, a zarazem liberalizacji prawa pracy ${ }^{5}$.

Jednym z fundamentalnych problemów współczesnego rynku pracy jest pogodzenie interesów pracodawców, pracowników, a także interesu publicznego. Podmioty zatrudniające chcą korzystać z instrumentów prawnych umożliwiających podejmowanie działań, które pozwolą na szybkie dostosowywanie się do zmiennej koniunktury gospodarczej. $Z$ kolei osoby świadczące pracę zainteresowane są stabilizacją zatrudnienia oraz utrzymaniem poziomu przysługujących im uprawnień. Ponadto utrzymanie miejsca pracy jest istotne nie tylko z perspektywy konkretnego przedsiębiorstwa i konkretnego pracownika. Ma ono znaczenie również dla interesu publicznego. Wynagrodzenie otrzymywane przez pracownika jest bowiem nie tylko źródłem jego zarobku, ale również przedmiotem opodatkowania oraz składek z zakresu ubezpieczenia społecznego. Zakończenie umowy oznacza brak tych dochodów na rzecz państwa, a zwolniony pracownik staje się ponadto beneficjentem świadczeń dla bezrobotnych ${ }^{6}$.

Bez wątpienia dla pracownika najkorzystniejsza jest umowa o pracę na czas nieokreślony. Inne formy zatrudnienia, często zwane atypowymi, również mają rację bytu na współczesnym rynku pracy. Konieczne jest zarazem, aby osoby świadczące pracę w ten sposób były chronione przed nadużyciami. Istotne jest również, że prawna forma aktywności zawodowej jest wyznacznikiem szeroko rozumianego statutu socjalnego jednostki, zwłaszcza w odniesieniu do stabilizacji zatrudnienia lub ochrony z zakresu zabezpieczenia społecznego ${ }^{7}$.

${ }^{4}$ P. Cahuc, For a unified contract, "European Labour Law Journal" 2012, vol. 3, No 3, s. 191.

${ }^{5}$ Zob. np. L. Florek, Granice liberalizacji prawa pracy, [w:] E. Bielak, H. Lewandowski (red.), Granice liberalizacji prawa pracy. Problemy zabezpieczenia społecznego. Materiały z XIV Zjazdu Katedr (Zakładów) Prawa Pracy i Ubezpieczeń Społecznych, Łódź 2003, s. 9 i nast.; H. Lewandowski, Granice liberalizacji prawa pracy, [w:] E. Bielak, H. Lewandowski (red.) Granice liberalizacji..., s. 27 i nast.

6 P. Cahuc, For a unified..., s. 194-195.

7 Szerzej L. Mitrus, Praca zarobkowa a bezpieczeństwo socjalne (uwagi na tle przeksztatceń rynku pracy), [w:] Księga Jubileuszowa Profesor Teresy Liszcz, Lublin 2015 oraz przytoczone tam piśmiennictwo. 
W przeciwieństwie do w miarę stabilnej sytuacji sprzed lat, fundamentalnym problemem współczesnego rynku pracy w Polsce, podobnie jak w innych krajach, jest jego głęboka segmentacja. Można wręcz mówić o dwubiegunowości świata pracy. Z jednej strony mamy zatrudnionych na stałe "pracowników wewnętrznych" (insiders), korzystających z pełni praw pracowniczych i socjalnych. Z drugiej natomiast strony pracowników „zewnętrznych" (outsiders), włącznie z osobami bezrobotnymi i wykluczonymi z rynku pracy, jak i osobami, których zatrudnienie jest niepewne i nieformalne. Ich status socjalny jest nieporównywalnie gorszy. Na kwestie te uwagę zwróciła m.in. Komisja Europejska, która w 2006 r. przedstawiła Zieloną Księgę poświęconą modernizacji prawa pracy w celu sprostania wyzwaniom XXI wieku' ${ }^{8}$. Celem księgi było zapoczątkowanie publicznej debaty $\mathrm{w}$ kwestii niezbędnych zmian prawa pracy oraz jego dostosowania do wymogów współczesności. W księdze podkreślono m.in., że uciekanie się do alternatywnych form zatrudnienia mogłoby stać się jeszcze bardziej powszechne przy braku możliwości wprowadzania zmian do standardowego wzoru umowy, które zapewniłyby większą elastyczność zarówno pracownikom, jak i przedsiębiorcom.

Pewnym remedium na poprawę sytuacji, zaproponowanym przez Komisję Europejską ma być koncepcja flexicurity ${ }^{9}$. Jej założeniem jest połączenie elastyczności zatrudnienia (flexibility) z jego bezpieczeństwem (security). Zasadniczymi komponentami nowego podejścia mają być elastyczne i pewne stosunki umowne (flexible and reliable contractual arrangements), systemy uczenia się przez całe życie, aktywna polityka rynku pracy oraz nowoczesne systemy zabezpieczenia społecznego. Podstawowym założeniem idei flexicurity jest zatem nie tyle ochrona konkretnego miejsca pracy, ile pozycji pracownika na rynku pracy (protect workers, not jobs). Dotyczy to przykładowo zwiększania szans na znalezienie kolejnego zatrudnienia, możliwości nabycia nowych kwalifikacji zawodowych, a także korzystania $\mathrm{z}$ odpowiedniego wsparcia w okresach bezrobocia. Zarysowana koncepcja doczekała się zróżnicowanych ocen w piśmiennictwie ${ }^{10}$. Nie ulega zarazem

${ }^{8}$ Commission of the European Communities. Green paper. Modernising labour law to meet the challenges of the $21^{\text {st }}$ century. Brussels, 22.11.2006. COM (2006) 708 final.

9 The European Commission's Communication on flexicurity: Towards Common Principles of Flexicurity. More and better jobs through flexibility and security, Brussels 27.06.2007, COM (2007) 359 final.

10 Zob. zwłaszcza krytyczne uwagi M. Seweryńskiego, Dylematy prawnej ochrony pracy, [w:] Z. Kubot, T. Kuczyński (red.), Z zagadnień prawa pracy i prawa socjalnego. Ksiega jubileuszowa Profesora Herberta Szurgacza, Warszawa 2011, s. 223 i nast. W polskim piśmiennictwie na temat koncepcji flexicurity por. również np. Z. Hajn, Ochrona trwałości stosunku pracy a flexicurity, [w:] G. Goździewicz (red.), Ochrona trwałości stosunku pracy w społecznej gospodarce rynkowej, Warszawa 2010, s. 87 i nast.; A. Patulski, Koncepcja flexicurity a nietypowe formy zatrudnienia, czyli jak ograniczyć segmentacje polskiego rynku pracy, [w:] A. Sobczyk 
wątpliwości, że stała się jednym z głównych punktów odniesienia toczącej się na poziomie Unii Europejskiej i w państwach członkowskich dyskusji na temat przyszłości prawa pracy. Należy również dodać, że Komisja sformułowała program dalszego rozwoju Unii Europejskiej, który w dużym stopniu uwzględnia kwestie społeczne, w tym dążenie do osiągnięcia wysokiego poziomu zatrudnienia ${ }^{11}$. W skład projektów przewodnich strategii „Europa 2020” wchodzą m.in. działania zmierzające do modernizacji prawa pracy oraz ułatwiania młodzieży wejścia na rynek pracy.

Jednym z elementów dyskusji zainicjowanej przez Komisję Europejską jest koncepcja jednolitej umowy o pracę. Propozycja przedstawiona została w komunikacie Enhancing labour market functioning, combatting segmentation: a proposal for "single" open - ended contract ${ }^{12}$. Idea ta koncentruje się na jednym z filarów flexicurity, a mianowicie na elastycznych i pewnych stosunkach umownych. Wpisuje się również w strategię „Europa 2020". We wspomnianym komunikacie Komisja Europejska podkreśliła, że segmentacja rynku pracy oznacza nie tylko różnicę w statusie poszczególnych osób, ale powoduje także zasadnicze trudności związane z przejściem od zatrudnienia terminowego do bezterminowego. Może to okazać się szczególnie dotkliwe dla osób młodych, które dopiero rozpoczynają karierę zawodową. Kolejną grupą narażoną na szczególnie duże uciążliwości są pracownicy o niskich kwalifikacjach, zwłaszcza jeżeli po okresie bezrobocia poszukują oni nowego zatrudnienia. Rzecz jasna, negatywne skutki zaistniałej sytuacji są dalej idące, np. w odniesieniu do niskiej produktywności czy ograniczonych możliwości podnoszenia kwalifikacji zawodowych w ramach umów terminowych, a także problemów z uzyskaniem w przyszłości świadczeń emerytalnych na zadowalającym poziomie.

3. Idea jednolitej umowy o pracę powstała około dziesięć lat temu w środowisku ekonomistów francuskich, którzy zaproponowali stworzenie jednolitego systemu ochrony zatrudnienia (fr. système unique de protection de l'emploi) oraz jednolitej umowy o pracę (fr. contrat de travail unique). Cel projektu był dwojaki: ograniczenie segmentacji rynku pracy oraz zredukowanie sztywnej ochrony standardowej umowy o pracę, zwłaszcza w odniesieniu do zwolnień z przyczyn ekonomicznych. W założeniu

(red.), Stosunki zatrudnienia w dwudziestoleciu społecznej gospodarki rynkowej. Ksiega pamiatkowa z okazji jubileuszu 40-lecia pracy naukowej Profesor Barbary Wagner, Warszawa 2010, s. 259 i nast.; M. Rycak, Wptyw koncepcji flexicurity na przemiany stosunku pracy, [w:] L. Florek, Ł. Pisarczyk (red.), Wspótczesne problemy prawa pracy i ubezpieczeń społecznych. XVIII Zjazd Katedr i Zakładów Prawa Pracy i Ubezpieczeń Społecznych, Warszawa, 26-28 maja 2011 r., Warszawa 2011, s. 211 i nast.

${ }^{11}$ Komunikat Komisji Europa 2020. Strategia na rzecz inteligentnego i zrównoważonego rozwoju sprzyjajacego właczeniu społecznemu, Bruksela 3.3.2010 KOM(2010) 2020 wersja ostateczna.

12 Enhancing labour market funcioning, combatting segmentation: a proposal for "single" open - ended contract. Commission note, EMCO/16/050411/EN. 
twórców koncepcji nowe uregulowania powinny przyczynić się do powstania bardziej płynnego rynku pracy oraz ułatwić tworzenie nowych miejsc pracy ${ }^{13}$.

W świetle propozycji Komisji Europejskiej, jednolita umowa o pracę jest umową na czas nieokreślony, która nie wskazuje z góry czasu swojego trwania. W odróżnieniu od aktualnych umów na czas nieokreślony, wprowadza wystarczająco długą fazę wstępną i stopniowy wzrost uprawnień wraz ze stażem pracy, z następującą następnie fazą stabilizacji ${ }^{14}$. Jednocześnie w ujęciu Komisji uprawnienia pracownicze miałyby się koncentrować na dwóch zasadniczych kategoriach: świadczeniach pieniężnych oraz ochronie przed wypowiedzeniem.

Uprawnienia pieniężne (ang. monetary rigths) sprowadzałyby się do rekompensaty finansowej w związku z wypowiedzeniem. Pracodawca byłby bowiem zobowiązany do wypłaty odprawy pieniężnej w każdym przypadku wypowiedzenia umowy. Prawo do odprawy istniałoby od momentu nawiązania umowy, a więc również w fazie wstępnej. Wysokość świadczenia wzrastałaby wraz z okresem zatrudnienia, przy czym ustalony byłby jej maksymalny pułap. Konieczność wypłaty odprawy miałaby zniechęcać pracodawców do pochopnego rozwiązywania umowy o pracę, a zarazem gwarantowałaby zwolnionemu pracownikowi zabezpieczenie źródła utrzymania, przynajmniej w pewnym zakresie.

Drugą kategorię środków zabezpieczających interes pracownika stanowiłyby uprawnienia związane z ochroną przed wypowiedzeniem (ang. legal rights). W komunikacie Komisji wskazano w tym kontekście okres wypowiedzenia, terminy wniesienia odwołania od wypowiedzenia oraz możliwość przywrócenia pracownika do pracy. Zakres i metody ochrony przed wypowiedzeniem byłyby uzależnione od regulacji przyjętych na poziomie państw członkowskich. Ustawodawca krajowy powinien zatem unormować dopuszczalność oraz przesłanki rozwiązania za wypowiedzeniem jednolitej umowy o pracę $w$ fazie jej stabilizacji. Nowo przyjmowane regulacje powinny uprościć stosowane procedury, co w praktyce mogłoby obniżyć poziom ochrony przed wypowiedzeniem. Zawsze niedozwolone byłoby dokonywanie wypowiedzeń opartych na którymś z kryteriów objętych zakazem dyskryminacji (np. płeć, rasa, wyznanie). Jak już wspomniano, zwolniony pracownik miałby prawo do świadczeń pieniężnych od pracodawcy.

13 Szerzej: G. Casale, A. Perulli, Towards the Single Employment Contract. Comparative Reflections, Hart Publishing, Oxford-Portland, Oregon, International Labour Office, Geneva 2014, s. 26 oraz wskazane tam dokumenty.

14 "The 'single' contract is an open - ended contract which has no ex-ante time limit, but contrasting with current open - ended contracts, provides sufficiently long entry phase and a gradual increase of protection rights increasing with seniority with a stability phase thereafter". Zob. Enhancing labour market functioning..., s. 6. 
Niezależnie od wskazanych wyżej uprawnień, jednolita umowa o pracę powodowałaby również narastanie innych praw, np. nabycie prawa do zasiłku dla bezrobotnych. Składki związane z umową stanowiłyby gwarancję uzyskania w przyszłości praw emerytalnych. Ponadto perspektywa długotrwałego trwania umowy zachęcałaby pracodawcę do „inwestowania" w pracownika, choćby w kwestii awansów lub szkoleń podnoszących kwalifikacje zawodowe.

Komisja Europejska uwypukliła kilka czynników decydujących o kształcie jednolitej umowy o pracę, w odniesieniu do których decyzje powinny zostać podjęte przez ustawodawców krajowych. Wśród tych parametrów należy wskazać długość wstępnej fazy umowy, sposób narastania uprawnień, kombinację świadczeń pieniężnych oraz ochrony przed wypowiedzeniem we wstępnej fazie umowy, maksymalną wysokość odprawy pieniężnej, a także inne koszty związane z umową. Należy dodać, że zgodnie z propozycją Komisji jednolita umowa miałaby obejmować nowo zawierane stosunki prawne. Nie ingerowałaby w już istniejące umowy na czas nieokreślony, a zatem nie powodowałaby pogorszenia sytuacji pracowników obecnie zatrudnionych na podstawie umowy bezterminowej ${ }^{15}$.

4. Jak dotąd, jednolita umowa o pracę w kształcie proponowanym przez Komisję Europejską nie została wprowadzona w żadnym państwie członkowskim. Zaawansowane dyskusje oraz prace legislacyjne zostały podjęte w Hiszpanii, Francji, a także we Włoszech ${ }^{16}$. W odniesieniu do Francji warto jednak zasygnalizować wcześniejsze próby ustanowienia nowego rodzaju umów, co odnotowano jeszcze przed nadejściem kryzysu gospodarczego. W 2005 r. wprowadzony został nowy rodzaj umowy contrat nouvelle embauche (umowa dla nowo zatrudnianych pracowników). Miała ona zastosowanie do podmiotów zatrudniających nie więcej niż 20 osób. Podczas dwuletniego okresu próbnego pracodawca mógł rozwiązać umowę bez podania przyczyny. Zwolnionemu pracownikowi przysługiwał jedynie okres wypowiedzenia oraz odprawa pieniężna. Na identycznych założeniach opierała się wprowadzona w 2006 r. umowa contrat première embauche (umowa o pierwsze zatrudnienie), była ona jednak adresowana do osób poniżej 26. roku życia. Umowy te miały w ustawodawstwie francuskim krótki żywot. Prawidłowość pierwszej z nich została zakwestionowana w 2008 r. w orzecznictwie sądowym ze względu na zbyt długi okres próbny, co uznano za sprzeczne z Konwencją nr 158

${ }_{15}$ Enhancing labour market functioning..., s. 6-10. Omówienie propozycji Komisji Europejskiej zob. G. Casale, A. Perulli, Towards the Single Employment..., s. 37 i nast.

${ }_{16}$ G. Casale, A. Perulli, Towards the Single Employment..., s. 47 i nast.; G. Loy, La réforme italienne: entre le malentendu de la flexicurité et la tentation du contrat unique, "Revue de Droit Comparé du Travail et de la Sécurité Sociale" 2012, No 2, s. 39 i nast. 
Międzynarodowej Organizacji Pracy dotyczącej rozwiązania stosunku pracy $\mathrm{z}$ inicjatywy pracodawcy ${ }^{17}$. Z drugiej ze wskazanych umów zrezygnowano już po kilku tygodniach wskutek protestów społecznych ${ }^{18}$. Otwarta pozostaje kwestia, czy ewentualne ustanowienie jednolitej umowy o pracę na czas nieokreślony zakończyłoby się w identyczny sposób.

Propozycja Komisji wskazuje tylko ogólne zarysy jednolitej umowy o pracę. Konkretne regulacje powinny zostać sprecyzowane na poziomie państw członkowskich. Dyskusyjna może być zwłaszcza długość wstępnej fazy umowy, która de facto byłaby okresem próbnym. Zbyt długie jej trwanie mogłoby oznaczać sprzeczność ze wspomnianą wyżej konwencją MOP nr 158. Fundamentalną kwestią byłoby również ustalenie zakresu ochrony przed wypowiedzeniem w fazie stabilizacji umowy (np. w kwestii przyczynowości wypowiedzenia), a także wysokość świadczeń pieniężnych przysługujących zwolnionemu pracownikowi.

W piśmiennictwie wskazuje się również inne elementy, które mogłyby stać się częścią jednolitej umowy o pracę. Przykładowo koszty obciążające pracodawcę w związku z wypowiedzeniem takiej umowy mogłyby obejmować nie tylko odszkodowanie dla zwolnionego pracownika, ale również podatek solidarnościowy na rzecz władz publicznych. W zamian za to przedsiębiorstwo byłoby zwolnione $\mathrm{z}$ innych zobowiązań, np. przeszkolenia pracownika ${ }^{19}$. Tego typu danina publiczna byłaby wykorzystywana przede wszystkim na finansowanie programów walki z bezrobociem, prowadzonych przez wyspecjalizowane instytucje państwowe ${ }^{20}$.

Należy też dodać, że status pracowniczy - niewątpliwie wynikający z zawarcia jednolitej umowy o pracę - oznaczałby pełnię praw z nim związanych, np. w odniesieniu do minimalnego wynagrodzenia, prawa do wypoczynku, prawa koalicji, a także pełnej ochrony z zakresu ubez-

17 Konwencja z dnia 2 czerwca 1982 r., nie ratyfikowana przez Polskę. Artykuł 2 ust. 2 b) pozwala na wyłączenie z zakresu ochrony przed wypowiedzeniem m.in. pracowników zatrudnionych na okres próbny, pod warunkiem, że długość tego okresu będzie określona z góry i w rozsądnym wymiarze. Tekst wskazanego aktu prawnego został opublikowany w: R.A. Henczel, R. Lemieszewska, M.D. Stefańska (red.), Konwencje i zalecenia Międzynarodowej Organizacji Pracy 1919-1994, t. II, 1967-1994, Warszawa 1996, s. 1084 i nast. Omówienie konwencji zob. np. L. Florek, M. Seweryński, Międzynarodowe prawo pracy, Warszawa 1988, s. 186 i nast.; A.M. Świątkowski, Międzynarodowe prawo pracy, t. I, Międzynarodowe publiczne prawo pracy - standardy międzynarodowe, Wolumen 3, Warszawa 2008, s. 8 i nast.

18 Więcej zob. G. Casale, A. Perulli, Towards the Single Employment..., s. 57 i nast.; S. Laulom, Dismissal law under challenge: new risks for workers, "European Labour Law Journal" 2014, vol. 5, No 3-4, s. 233-234.

19 Tak P. Cahuc, For a unified...: „The termination of the open - ended contract brings about the payment of an indemnity to the employee and a solidarity contribution - a tax paid to the public authorities" (s. 196). Cytowany autor należy do twórców koncepcji jednolitej umowy o pracę.

${ }^{20}$ P. Cahuc, For a unified..., s. 199 i nast. 
pieczeń społecznych. Element ten byłby atrakcyjny zwłaszcza dla osób wykonujących dotychczas działalność zarobkową poza stosunkiem pracy, np. na podstawie umów cywilnoprawnych.

5. Jednolitą umowę o pracę można zatem scharakteryzować jako umowę bezterminowa, w której decydujące znaczenie dla nabycia określonych uprawnień miałby staż pracy. Sytuacja pracownika ulegałaby stopniowej poprawie wraz ze zwiększaniem się okresu zatrudnienia. Faza wstępna stanowiłaby swego rodzaju okres próbny, podczas którego ochrona przysługująca pracownikowi byłaby ograniczona. Istotnym elementem jednolitej umowy o pracę byłoby płynne przejście z okresu próbnego do zatrudnienia bezterminowego. Nie byłoby wymagane zawarcie kolejnego stosunku pracy. $\mathrm{W}$ fazie stabilizacji pracownik korzystałby $\mathrm{z}$ ochrony przed wypowiedzeniem. Jej poziom mógłby być niższy w porównaniu $\mathrm{z}$ aktualnym stanem prawnym. Uproszczeniu mogłyby ulec procedury dokonywania zwolnień, a zakres roszczeń przysługujących pracownikowi mógłby zostać ograniczony. Z drugiej strony pracownikowi w każdej sytuacji przysługiwałoby prawo do odprawy pieniężnej. Zatem zwolnienie pracownika zatrudnionego bezterminowo byłoby łatwiejsze niż obecnie, ale pociągałoby za sobą dodatkowe koszty po stronie pracodawcy.

Na gruncie powyższych uwag można pokusić się o merytoryczną ocenę zaprezentowanej koncepcji. Zasadniczym skutkiem wprowadzenia jednolitej umowy o pracę byłaby likwidacja podziału umów o pracę na terminowe oraz bezterminowe. $W$ praktyce nastąpiłaby rezygnacja $\mathrm{z}$ umów terminowych $\mathrm{w}$ tradycyjnym rozumieniu tego pojęcia. Celowość takiego zabiegu budzi poważne wątpliwości. Umowy terminowe mają swój cel i przeznaczenie, a w wielu przypadkach odpowiadają interesom obydwóch stron. Bez wątpienia problemem jest natomiast nadużywanie zatrudnienia terminowego. Powtarzające się umowy tego rodzaju moga okazać się swoistą pułapka, w praktyce uniemożliwiającą powstanie bezterminowego stosunku pracy. Mogą zarazem utrwalać zatrudnienie nietrwałe i niepewne, które jest również określane jako prekariat.

Z powyższych względów na podkreślenie zasługuje fakt, że jednym z celów Komisji Europejskiej jest ułatwianie przechodzenia od zatrudnienia terminowego do bezterminowego. Chodzi o fazę wstępną jednolitej umowy o pracę, która następnie przechodziłaby automatycznie $\mathrm{w}$ fazę stabilizacji. Powstaje jednak pytanie, czy celu tego nie można skutecznie osiągnąć korzystając z już istniejących instrumentów prawnych. De lege lata nie ma bowiem żadnych przeszkód lub ograniczeń, aby pracodawca pozytywnie oceniający pracownika w okresie próbnym zawarł z nim umowę na czas nieokreślony. Ponadto odpowiednim środkiem wydaje się zwłaszcza mechanizm zapobiegania nadużyciom przewidziany 
art. 5 dyrektywy 99/70²1, który polega na określeniu maksymalnej łącznej długości umów na czas określony. Po upływie wskazanego w ustawodawstwie krajowym okresu umowa terminowa przekształca się automatycznie w umowę na czas nieokreślony. Takie właśnie uregulowanie jest obecnie w Polsce przedmiotem zaawansowanych prac legislacyjnych. Celem nowelizacji jest odstąpienie od nieskutecznej konstrukcji wynikającej $\mathrm{z}$ art. $25^{1} \mathrm{kp}$, na podstawie którego trzecia $\mathrm{z}$ kolei umowa na czas określony przekształca się $\mathrm{w}$ umowę bezterminową.

Warto również zauważyć, że mechanizm oparty na zwiększaniu uprawnień pracowniczych wraz z okresem zatrudnienia nie jest niczym nowym. Wręcz przeciwnie, narastanie uprawnień pracowniczych ze wzrostem stażu pracy jest niejako wpisane w istotę umowy o pracę jako zobowiązania o charakterze ciągłym ${ }^{22}$. Konstrukcja ta może obejmować zarówno okres wyczekiwania na objęcie pracownika ochroną przed wypowiedzeniem, jak i powiązanie ze stażem pracy wysokości świadczeń pieniężnych związanych z ustaniem umowy. Z tej perspektywy jednolita umowa o pracę nawiązuje do już istniejących konstrukcji prawa pracy.

Sądzę zarazem, że na szczególną uwagę zasługuje problematyka obciążeń finansowych, które byłyby związane $\mathrm{z}$ wypowiedzeniem jednolitej umowy o pracę. Kwestie fiskalne nie są regulowane bezpośrednio przez prawo pracy. Jednocześnie koszty pracy są bez wątpienia jednym z zasadniczych elementów branych przez pracodawcę pod uwagę przy zatrudnieniu pracownika lub jego zwolnieniu. Zbyt wysokie obciążenia mogą też skłaniać pracodawców do obchodzenia prawa pracy, zwłaszcza poprzez umowy cywilnoprawne, zawierane zamiast umów o pracę, a także zatrudnienie nielegalne (nierejestrowane). Instrumenty finansowe lub zmniejszenie zróżnicowania obciążeń finansowych poszczególnych form świadczenia pracy (np. podatków czy składek ubezpieczeniowych) mogą okazać się skuteczniejsze niż sankcje za naruszenie prawa pracy (np. odpowiedzialność za wykroczenia przeciwko prawom pracownika) $)^{23}$.

W chwili obecnej brak jest instrumentów finansowych, które zniechęcałyby do stosowania powtarzających się umów terminowych. Ustanie umowy wskutek nadejścia uzgodnionego terminu nie zobowiązuje pracodawcy do wypłaty odprawy. Ponadto na gruncie prawa polskiego odprawa pieniężna jest związana tylko z wypowiedzeniem z przyczyn

${ }^{21}$ Dyrektywa Rady 99/70/WE z dnia 28 czerwca 1999 r. dotycząca Porozumienia ramowego w sprawie pracy na czas określony, zawartego przez Europejską Unię Konfederacji Przemysłowych i Pracodawców (UNICE), Europejskie Centrum Przedsiębiorstw Publicznych (CEEP) oraz Europejską Konfederację Związków Zawodowych (ETUC), DzUrz WE nr L 175 z 10 lipca 1999 r., s. 43 (DzUrz UE, Wyd. Sp., rozdz. V, t. III, 368).

${ }^{22}$ Więcej zwłaszcza P. Walorska, Staż pracy, Warszawa 2014, s. 123 i nast. oraz s. 255.

${ }^{23}$ Szerzej L. Mitrus, The Fight Against Undeclared Work: Sanctions and Incentives, „European Labour Law Journal" 2014, vol. 5, No 2, s. 174 i nast. 
leżących po stronie zakładu pracy. Świadczenie to nie przysługuje w razie rozwiązania umowy z powodów dotyczących pracownika. Jednolita umowa o pracę zakłada wypłatę odprawy w każdym przypadku jej wypowiedzenia przez pracodawcę. Zatem dla podmiotu zatrudniającego zwolnienie pracownika zawsze wiązałoby się z dodatkowymi obciążeniami finansowymi, co mogłoby zniechęcać do wypowiedzeń pochopnych lub nieuzasadnionych merytorycznie. Jednocześnie pracodawca zapewniający załodze stabilizację zatrudnienia nie ponosiłby takich kosztów.

Interesująca jest również zaprezentowana w literaturze koncepcja nałożenia na pracodawcę wypowiadającego jednolitą umowę o pracę obowiązku uiszczenia podatku solidarnościowego ${ }^{24}$. Byłby on co do zasady przeznaczony na walkę z bezrobociem, prowadzoną przez wyspecjalizowane instytucje państwowe. Należy poczynić w tym miejscu istotne zastrzeżenie. W odniesieniu do rozwiązania za wypowiedzeniem umowy o pracę na czas nieokreślony polskie ustawodawstwo wymaga istnienia przyczyny oraz dochowania odpowiednich procedur. Natomiast niektóre systemy prawne nakładają na pracodawców powinność podjęcia wcześniejszych działań, które mają na celu uniknięcie zwolnień. Przykładowo może to być obniżenie wymiaru czasy pracy, powierzenie pracownikowi pracy innego rodzaju, jego przeszkolenie lub wcześniejsze upomnienie dające szansę poprawy bądź też rozważenie działań restrukturyzacyjnych wewnątrz przedsiębiorstwa ${ }^{25}$. Podatek solidarnościowy miałby zwolnić pracodawców z tego typu obowiązków, nierzadko związanych z ponoszeniem kosztów finansowych. Jego istotą jest zatem zwolnienie pracodawców z określonych powinności względem pracowników na rzecz uiszczenia daniny publicznej na rzecz państwa. W polskich realiach byłoby to jedynie dodatkowe obciążenie finansowe nałożone na pracodawców, nie równoważone żadnymi innymi korzyściami.

6. W podsumowaniu należy podkreślić, że Komisja Europejska nie dąży do narzucenia państwom członkowskim jednolitej umowy o pracę. Nie jest dyskutowana dyrektywa, która potencjalnie mogłaby zobowiązać władze krajowe do wprowadzenia umowy takiego rodzaju. Propozycję Komisji należy zatem traktować jako sugestię odnośnie do potencjalnych działań ograniczających segmentację rynku pracy, które mogłyby zostać podjęte na szczeblu krajowym. Nie powinna budzić wątpliwości celowość poszukiwania rozwiązań legislacyjnych, które poprawią sytuację w dziedzinie zatrudnienia. $Z$ tej perspektywy koncepcja jednolitej umowy o pracę zasługuje na zainteresowanie, może również stanowić impuls do dalszej dyskusji w kwestii sytuacji na rynku pracy.

${ }^{24}$ Zob. wyżej przypis 19.

${ }^{25}$ Odnośnie do obowiązków wynikających z prawa francuskiego zob. np. J. Pélissier, G. Auzero, E. Dockés, Droit du travail, 26e edition, Paris 2011, s. 519 i nast. 
Otwarte jest pytanie, czy pracodawcy rzeczywiście byliby bardziej skłonni do zatrudniania pracowników, wiedząc że w długiej perspektywie czasowej zwolnienie będzie łatwiejsze merytorycznie, choć związane z dodatkowymi obciążeniami finansowymi. Trudno również lekceważyć obawy, że wprowadzenie jednolitej umowy o pracę spowoduje ograniczenie aktualnie obowiązującej ochrony przed wypowiedzeniem bezterminowych umów o pracę. Ponadto zbyt długa faza wstępna umowy, która mogłaby być dłuższa od dzisiejszych okresów próbnych, w zasadzie nie gwarantowałaby pracownikom żadnej stabilizacji. W szerszej perspektywie wprowadzenie jednolitej umowy o pracę wcale nie musiałoby okazać się więc korzystne dla uczestników rynku pracy.

Trzeba też przypomnieć, że zgodnie z komunikatem Komisji proponowany rodzaj umowy obejmowałby jedynie nowo zawierane stosunki prawne. W tym wariancie jednolita umowa o pracę na czas nieokreślony - zakładając, że koncepcja taka zyskałaby rację bytu - mogłaby stać się wiodącą formą zatrudnienia dopiero po upływie kilku dekad. Sądzę jednak, że działania zmierzające do zwalczania segmentacji rynku pracy są nakazem chwili oraz powinny być nakierowane na osiągnięcie rezultatu w zdecydowanie krótszej perspektywie czasowej.

Można zatem stwierdzić, że koncepcja jednolitej umowy o pracę na czas nieokreślony budzi więcej wątpliwości niż wskazuje potencjalnych korzyści. Na pewno ustanowienie takiej umowy, w oderwaniu od innych środków, nie rozwiązałoby istniejących problemów. Zwalczanie segmentacji rynku pracy wymaga wszechstronnych oraz daleko idących reform. Jednolita umowa o pracę nie wydaje się jednak adekwatnym kierunkiem działań dla polskiego ustawodawcy.

\section{Bibliografia}

Cahuc P., For a unified contract, „European Labour Law Journal” 2012, vol. 3, No 3.

Casale G., Perulli A., Towards the Single Employment Contract. Comparative Reflections, Hart Publishing, Oxford-Portland, Oregon, International Labour Office, Geneva 2014.

Commission of the European Communities. Green paper. Modernising labour law to meet the challenges of the $21^{\text {st }}$ century, Brussels, 22.11.2006. COM (2006) 708 final.

Enhancing labour market funcioning, combatting segmentation: a proposal for "single" open - ended contract. Commission note, EMCO/16/050411/EN.

The European Commission's Communication on flexicurity: Towards Common Principles of Flexicurity. More and better jobs through flexibility and security, Brussels 27.06.2007, COM (2007) 359 final.

Florek L., Granice liberalizacji prawa pracy, [w:] E. Bielak, H. Lewandowski (red.), Granice liberalizacji prawa pracy. Problemy zabezpieczenia społecznego. Materiaty z XIV Zjazdu Katedr (Zakładów) Prawa Pracy i Ubezpieczeń Społecznych, Łódź 2003.

Florek L., M. Seweryński, Międzynarodowe prawo pracy, Warszawa 1988. 
Jednolita umowa o pracę na czas nieokreślony?

Gersdorf M., Prawo zatrudnienia, Warszawa 2013.

Hajn Z., Ochrona trwałości stosunku pracy a flexicurity, [w:] G. Goździewicz (red.), Ochrona trwałości stosunku pracy w społecznej gospodarce rynkowej, Warszawa 2010.

Henczel R.A., Lemieszewska R., Stefańska M.D. (red.), Konwencje i zalecenia Międzynarodowej Organizacji Pracy 1919-1994, t. II, 1967-1994, Warszawa 1996.

Komunikat Komisji Europa 2020. Strategia na rzecz inteligentnego i zrównoważonego rozwoju sprzyjającego właczeniu społecznemu, Bruksela 3.3.2010 KOM(2010) 2020 wersja ostateczna.

Laulom S., Dismissal law under challenge: new risks for workers, „European Labour Law Journal" 2014, vol. 5, No 3-4.

Lewandowski H., Granice liberalizacji prawa pracy, [w:] E. Bielak, H. Lewandowski (red.), Granice liberalizacji prawa pracy. Problemy zabezpieczenia społecznego. Materiaty z XIV Zjazdu Katedr (Zakładów) Prawa Pracy i Ubezpieczeń Społecznych, Łódź 2003.

Loy G., La réforme italienne: entre le malentendu de la flexicurité et la tentation du contrat unique, „Revue de Droit Comparé du Travail et de la Sécurité Sociale” 2012, No 2.

Mitrus L., The Fight Against Undeclared Work: Sanctions and Incentives, „European Labour Law Journal" 2014, vol. 5, No 2.

Mitrus L., Praca zarobkowa a bezpieczeństwo socjalne (uwagi na tle przeksztatceń rynku pracy), [w:] Ksiega Jubileuszowa Profesor Teresy Liszcz, Lublin 2015.

Patulski A., Koncepcja flexicurity a nietypowe formy zatrudnienia, czyli jak ograniczyć segmentację polskiego rynku pracy, [w:] A. Sobczyk (red.), Stosunki zatrudnienia w dwudziestoleciu społecznej gospodarki rynkowej. Księga pamiątkowa z okazji jubileuszu 40-lecia pracy naukowej Profesor Barbary Wagner, Warszawa 2010.

Pélissier J., Auzero G., Dockés E., Droit du travail, 26 edition, Paris 2011.

Rycak M., Wpływ koncepcji flexicurity na przemiany stosunku pracy, [w:] L. Florek, Ł. Pisarczyk (red.), Współczesne problemy prawa pracy i ubezpieczeń społecznych. XVIII Zjazd Katedr i Zakładów Prawa Pracy i Ubezpieczeń Społecznych, Warszawa, 26-28 maja 2011 r., Warszawa 2011.

Seweryński M., Dylematy prawnej ochrony pracy, [w:] Z. Kubot, T. Kuczyński (red.), Z zagadnień prawa pracy i prawa socjalnego. Księga jubileuszowa Profesora Herberta Szurgacza, Warszawa 2011.

Seweryński M., Kryzys gospodarczy i prawo pracy, [w:] G. Uścińska (red.), Prawo pracy. Refleksje i poszukiwania. Księga Jubileuszowa Profesora Jerzego Wratnego, Warszawa 2013.

Świątkowski A.M., Międzynarodowe prawo pracy, t. I, Międzynarodowe publiczne prawo pracy - standardy międzynarodowe, vol. 3, Warszawa 2008.

Veneziani B., The Employment Relationship, [w:] B. Hepple, B. Veneziani (red.), The Transformation of Labour Law in Europe. A comparative study of 15 countries 1945-2004, OxfordPortland, Oregon 2009.

Walorska P., Staż pracy, Warszawa 2014.

\section{The Single Open - ended Employment Contract?}

\section{Summary}

The present chapter is dedicated to the analysis of the concept of the single open - ended employment contract. Such an idea is promoted by the European Commission. It also constitutes a subject of the discussion in several EU Member States. The single employment contract can be defined as an open - ended contract which has no ex-ante time 
limit, but contrasting with current open - ended contracts, provides sufficiently long entry phase and a gradual increase of protection rights increasing with seniority, with a stability phase thereafter. According to the concept, employees would be protected against dismissal by monetary rights, i.e. the severance payment that increases with seniority, as well as legal rights, such as e.g. notification procedure, maximum time for claim or possibility of reinstatement. In addition, employers who dismiss employees would be obliged to comply with some public duties, e.g. paying a solidarity tax dedicated to the financing of unemployment scheme. The basic aim of the open - ended contract would be to countervail a deep segmentation of national labour markets and to facilitate a transition from fixed - term to permanent employment. In general, Author critically evaluates the above-mentioned concept as an appropriate way of further development of labour law. 